\title{
The first complete scientific grammar of Skolt Saami in English
}

Tiмотнy Feist: A Grammar of Skolt Saami. Mémoires de la Société Finno-Ougrienne 273. Finno-Ugrian Society. Helsinki 2015. 414 p.

The aim of the book in question is to provide an overview of the structure of Skolt Saami and to serve as a tool for theoretical linguists and typologists as well as a resource for the language community and others interested in Saami languages. It consists of an introduction, nine chapters on the phonology, morphology and syntax of Skolt Saami, paying particular attention to its highly complex morphophonological and inflectional systems, and four texts translated into English and analyzed by means of interlinear glosses. The aim of this grammar is to describe the structure of the language in a way that makes it accessible to the widest possible audience and useful to scholars regardless of their particular theoretical framework. It avoids focusing on a particular theory and follows the framework known as "Basic Linguistic Theory". The methodology used in preparing the grammar comes from descriptive field linguistics.

Skolt Saami is not a language lacking previous investigation, rather it has been the object of scientific research for over 150 years. Earlier research, it should be noted, has placed special focus on lexicon and what comparative linguistics can tell us of the diachronic development of Skolt Saami; an approach depictive of that era in Finno-Ugrian language research. In addition to its diverse approach, access to earlier research by modern linguists has been encumbered by the mere fact that the majority of research was written in either German or Finnish. This work by Tim Feist has clearly opened a new English-language forum for Skolt Saami studies.

Skolt Saami, as is the case of many if not all languages, is divided into areal variants, i.e. dialects. The language was traditionally spoken on both sides of what is today the Russian-Norwegian border. As is vividly depicted in the introductory chapter of the grammar, the major- 
ity of Skolt Saamis no longer live in their traditional home, centered around Pechenga (Skolt Saami: Peäccam; Finnish: Petsamo). After World War I, Pechenga was made part of Finland and its inhabitants Finnish citizens. After World War II, however, the lands were ceded to the Soviet Union without their inhabitants, who had been evacuated to other parts of Finland. The transfer of the population to a new home, northwest and southeast of Lake Inari in Finnish Lapland, the general modernization of the Skolt Saami community and an increased contact with the Finnish language have all had a dramatic influence on the status of the Skolt Saami language and its structure. The traditional dialects have been joined by new language variants manifest with combinations of old dialect features and innovations. Variation has also been affected by the written language taught in schools, which was developed some fifty years ago and based on the Suonjel (Finnish: Suonikylä) dialect.

The first description of a Skolt Saami standard literary language was forwarded by Mikko Korhonen in "Main points of the grammar" (1973). This had been preceded by an article by the same author: "Proposal for a phonematic transcription of the Skolt Saami Suonjel dialect" (Korhonen 1971). Both are mentioned in the sources of Feist's grammar - the former is also mentioned in the introduction - but the only reference made to either of them is in the discussion of plosives (pp. 46, 50). The dictionary by Pekka Sammallahti and Jouni Moshnikoff (SKoS 1991) is also mentioned in the introductory. It contains a presentation of Skolt Saami verbal and nominal inflection types with the help of model words; the same inflection models are included in the "School Grammar of Skolt Saami" (Kk 2009) by Satu \& Jouni Moshnikoff and Eino Koponen. The inflection classes and model words introduced by Feist are also based on these same basic classifications, which will be dealt with in more depth below.

In the sources, materials included, there are a good 50 works mentioned. In the text, however, source references are so infrequent, that one contemplates whether all sources have actually been referenced. Part of the references are quite vague or unexpected: for example, Ylikoski 2009 is mentioned on page 201 without anything more specific such as providing a thorough treatment of non-finites in North Saami and touching on some of the terminological issues surrounding them, when dealing with the connegative form on page 229, however, a specific page is also given. In contrast, 
Mikko Korhonen's classic Die Konjugation im Lappischen $(1967,1974)$ is neither mentioned in the text nor the sources. Of more recent literature, those not mentioned and yet important from a descriptive and typological stand point are: "Skolt Saami: a typological profile" by Matti Miestamo (2011) and "Negation in Skolt Saami” by Miestamo \& Koponen (2015); of these the latter may not have been published until after the final draft of this grammar was prepared, and the former did not appear until after the first version of this grammar appeared as a net version (2010). In defence of the author, let it be said that, in general, grammars do not make reference to earlier literature as much as is the case in other types of research.

The main part of chapter 2 deals with the segmental phonemes of Skolt Saami. The description is enlightening and also contains results of the author's own experimental research along with observations on interspeaker variation as well as the major tendencies in sound change in Skolt Saami. The author also takes a stand on one phonological point of contention, namely the status of "ẹ" / $/ \varepsilon /$ as a possible $10^{\text {th }}$ vowel phoneme. ${ }^{1}$ This issue is especially intertwined with the phonological interpretation of diphthongs containing this component. Feist maintains that there is no tenth vowel phoneme, but instead diphthongs containing this component are allophones of other diphthongs. We will return to this issue later on. As Feist himself states, the issue is riddled with interspeaker variation.

Chapter 4 provides a short overview of each of the word classes in Skolt Saami. In the first three sections, the three open word classes, verbs, nouns and adjectives, are briefly introduced. The subsequent sections cover the closed word classes of pronouns, numerals, quantifiers, adverbs, adpositions and particles. Adjectives are addressed in subsection 4.3, and it is stated that they serve primarly to modify nouns, but there are some cases where an adjective can function as the head of a noun phrase, taking case and number marking in the same way as nouns. In contrast to nouns, adjectives have special attributive forms, which unlike their noun-like predicative forms do not inflect. Despite the fact that the concepts "attributive form" and "predicative form" are self-evident to readers familiar with earlier literature, it would have been expedient to indicate the subsections 7.2.1 and 10.3, where the syntactic functions of these forms are dealt with at greater length. This would have been especially well-founded when dealing with the attributive form, since the name of its syntactic func- 
tion in this presentation is not the familiar term "attribute" but "nominal modifier", whereas reference to scope and the noun phrase might have been more to the point.

Pronouns (personal, reflexive, demonstrative, indefinite, distributive, negative, relative and interrogative) are all presented in subsection 4.4 and complete paradigms are given in subsection 6.3. When demonstrative pronoun usage as determiners is introduced in subsection 7.2.3, it is noted that unlike adjectives and verbal participles, demonstratives, when functioning as determiners, display what can be referred to as partial agreement with the NP head. The same type of partial congruence, it should be noted, is also possible when the adnominal modifier is in a comparative or superlative form or involves the derivational endings: -laž, -važ, -lvaž, -saž (see Kk p. 48). The numerals (cardinals and ordinals) are presented in subsection 4.5 and the cardinals used as determiners are presented with their characteristic partial congruence in subsection 7.2.5. The fact that numerals (as well as adjectives) can at times function as the heads of noun phrases, where they have complete paradigms (e.g. u'vddem tie'ğğ kähcca give.V.Ind.Prt.Sg1 money.N.Sg.Acc eight.Num.Sg.Dat 'I gave money to eight [people]'), does not seem to be mentioned anywhere, and although a partial paradigm is given for the numerals 'one', 'two' and 'eight' in 7.2.5, they are not dealt with in chapter 6 at all.

Unexpectedly, syntax has been divided into two separate chapters, such that the noun phrase is dealt with in chapter 7 directly after nominal inflection in chapter 6 , and clausal syntax comes in chapter 10 after verbal inflection in chapter 8 and chapter 9 on tense, aspect, mood and polarity. This solution is, in its own way, logical, and the same principle might have been applied to word formation as well, whereby nominal word formation (derivation and combining) would have formed its own chapter between nominal inflection and noun phrase syntax. Likewise word formation for verbs (derivation only) would have come as its own chapter before clausal syntax, which has the subsection 10.4 dealing with voice and valence in deverbal verb derivation from a syntactic perspective. While dealing with deverbal verbs it would have been clearer to mention the two-way division: aspect changing (subitive, diminutive, continuative) and valence changing (causative, reflexive/reciprocal, middle) (cf. Nickel \& Sammallahti 2011: 541). The central part of chapter 10 consists of nominal phrases case-for-case as arguments of the 
verb. At the beginning of the chapter there is an analysis of constituent order based on a small amount of material, of which it is stated that clearly the most common ordering of clauses with two constituents is SV and OV, but, in the case of clauses with three constituents, the order SVO is more common than SOV.

Chapter 9 addresses Skolt Saami tense, aspect, mood and polarity in their own subsections. Tense is dealt with in the traditional way, dividing the two morphologically marked, absolute tenses (present and past), and the two periphrastically marked, relative tenses (present perfect and past perfect), the latter of which are formed with the combination of the verb lee'd 'to be' and the past participle form of the main verb. Aspectual meanings can be expressed by means of various verbal constructions or derivational suffixes, including: (i) periphrastic use of an auxiliary verb; (ii) periphrastic use of a participial aspectual construction, or (iii) use a morphological marker on the verb. The participial aspectual construction here indicates the verb lee'd 'to be' and the progressive participle form used with it. This construction, as is the case with other non-person-marked verb forms, is presented in chapter 8 . (The use of non-finite verb forms is presumably distributed throughout the other chapters; it would have been good to indicate their placement.) In chapter 8 , the conjugation of moods (conditional, potential, imperative and, of course, indicative present and preterite) are given along with connegative forms for the four moods. The weight of chapter 9 falls on the description of functions (syntactic use) of forms. The negative forms of the irreal moods are addressed together with the positive forms, and in the subsection on polarity it is mainly the indicative that is dealt with in sentences of negation. The imperative and its use in negative sentences, however, is not mentioned at all in subsection 9.4. The fact that the negative preterite is formed through a combination of the negative auxiliary and the past participle, is only implicitly referred to in example (64).

In chapters 7,9 and 10, the presentation is exemplified throughout with constructions and sentences that, for the most part, come from the textbook Maaddârää'jji mainnâz ('Tales of Our Forefathers'; Mosnikoff 1992) but also from Skolt Saami recordings at Suomen kielen nauhoitearkisto as well as a few occasional recording from other sources. The sources and their abbreviations are presented in chapter 1.6. These examples with interlinear glossing as well as the glossed texts in chapter 11 enhance the useful- 
ness of this book on Skolt Saami in the hands of typologist and general linguistic readers who lack a working knowledge of the language. Although the abbreviations used in the glosses can easily be guessed at, for the main part, it would have been better if they had been addressed in a list of abbreviations as is standard practice. The usefulness of the work could have been further augmented by providing a thematic index for simplified location of where specific issues were addressed.

In chapter 8 of the grammar under scrutity, the Skolt Saami verbs have been divided into four classes, a division that can be reached utilizing the inflection types in SKoS. Three of the four classes are further divided into three groups (Feist: Group A, B and C) according to the vowel height and presence or absence of palatalization in the vowel centre (in final stress group) of the verb. In class 1 this can also be observed in the quality of the latus, i.e. the vowel $(\hat{a}, a, e)$ preceding the infinitive ending $-d$. In classes 2 and 4, the height/palatalization of the vowel centre, i.e. the first syllable, is just as relevant. This same set of criteria could have also been applied to class 3 , where the connegative form (equal to the second person singular imperative) can be defined in a parallel fashion to what is found in classes 1, 2 and 4, (e.g. kuõccjed 'to rot' - ij kuõccâg; čåuddjed 'to come loose' - ij čouddu, and võ'll'jed 'to jump' - ij võ'lle). It is questionable, whether the verbs of type kuorccjed belong synchronically to class 3 or class 2 (from a comparative linguistic perspective they would belong to the latter). Feist's stand on this matter remains unclear, because he does not mention this type at all. Since the infinitive and all paradigmatic forms other than the connegative and second person singular imperative are identical to what would be found in class 3 , it would be possible to speak of the kuõccjed type as a third group of class 3. In contrast to the four classes posed by Feist, Korhonen (1973) has two conjunction classes: those undergoing gradation (Feist: class 1), and those without gradation. The latter class is subdivided into two, non-contracted (Feist: class 2) and contracted, which Feist divides into two (classes 3 and 4). Korhonen's division is diachronically motivated but synchonically problematic, since the $-j$ - contraction of class 3 undergoes quite a different morphophonematic variation from that found in the - $d$-contraction of class 4 (kârreed-ij kârrad).

Feist divides the nominal types (chap. 6) into twelve declension classes, of which some are further divided into subclasses according to criteria such as those forwarded 
for verbal conjugation. Korhonen divides nominal types into five declension classes, of which the first contains Feist's classes 1, 5 and 10. Korhonen's second class is split into two subclasses: one without gradation (Feist: 7 and 8), and one with gradation (Feist: 4, which could have contained more examples). Korhonen's third class is equal to Feist's 2A and 3. Korhonen's fourth declension class include present participles (from verbs of the first verbal conjugation class), which Feist indicates in class 6. The fourth declension class by Korhonen comprises of contracted stem nominals, which Feist categorizes as class ${ }_{2} \mathrm{~B}$ and 9 , in addition to a portion that have been left out as irregular words.

In subsections 4.3 and again in 6.4 , it is stated that a majority of adjective declension is confined to the nominal declension classes 1 , 4, 8 and 11. Of these, the last mentioned is comprised almost entirely of $d$-final adjectives with only a few nouns, such as jeä'med 'lady of the house' and ee'žžed 'master of the house' (jeä'meest 'lady of the house.N.Sg.Loc' etc.). According to $\mathrm{Kk}$ these nouns can decline according to a class 8 pattern, as well (jeä'mdest etc.). Declension class 12 consists of comparative forms of the class 11 adjectives, with the comparative form moččääb 'more beautiful' given as an example of the adjective mooččâd 'beautiful'. The paradigmatic forms differ to some extent from those given in $\mathrm{Kk}$ (p. 53) and those provided by SKoS (pp. 190-191), as well as Sammallahti (2012: 151). The comparative form uu'ccab 'smaller' of the class 1 adjective $u^{\prime} c c$ 'little' is also said to decline according to class 12 rules with the form uu'ccõ'bbe 'smaller.A.Sg.Ill' etc. It is quite plausible that the author has been given such analogical forms by informants, but according to other sources, e.g. Kk (p. 52); SKoS (p. 188) and Korhonen (1973: 57), they belong to class 8 (Sg.Ill. uu'ccba, Sg.Loc. uu'ccbest etc.). The formation of attributive forms for comparative and superlative adjectives are provided in subsection 6.4. Superlative paradigms, however, are not presented.

The inflection classes in Feist's grammar are based on morphophonological alternation that can be observed synchronically in verbs and nominals. They are described according to explicit rules and concepts developed in the third chapter, dealing with morphophonology. The description is purely synchronic and it departs from the pretext (diachronically problematic) that the nominal inflection can be derived from nominative singular forms, and verbal inflection, likewise, from the infinitive. 
Important concepts include vowel height and gradation. This is where two features belonging to Skolt Saami suprasegmental phonology, palatalization and quantity, show prominence in the vowels of the (primary and secondary) stressed syllables and subsequent consonantisms.

One feature common to all Saami languages and therefore posited as proto-Saamic is that word forms that were originally four syllables in length are divided into two stress groups or feet such that the first, stressed syllable and second, unstressed syllable comprise one foot, while the third, secondarily stressed syllable and fourth, unstressed syllable comprise a second foot. One example of such a four-syllabled proto-Saamic word can be found in the modern Northern Saami word logahallá 'enumerate.V.Prs.Sg3', where the first foot is $\log a$ - and the second is -hallá. The Skolt Saami equivalent is looggtââll. It may be disputed just how many syllables there are in the Skolt Saami word, but regardless of how it is analyzed the Skolt Saami word also consists of two feet, loogg- and -tââll.

Since the final syllable of proto-Saamic is always posited as unstressed, three-syllable words have consisted of one foot with one stressed syllable and two un- stressed syllables. Examples of such proto-Saamic words might be found represented in the modern Northern Saami word forms muitalan 'tell.V.Prs.Sg1' and gieđas 'hand/arm.N.Sg.Loc' as well as the Skolt Saami equivalents mušttlam and $\check{k i o \tilde{a} a ̂ s t . ~ A s ~ c a n ~ b e ~ s e e n ~ i n ~ t h e ~}$ examples, Northern Saami has retained the original number of syllables in some instances (muitalan), whereas elsewhere the number of syllables has been reduced to two (giedas). Thus the Northern Saami word muitalan represents the foot type posited for three-syllable proto-Saamic feet, whose components, using Sammallahti's terminology (1998: 39) can be represented by initium $(m)$, vowel centre $(u)$, consonant centre (it), latus (a), consonant margin $(l)$, vowel margin $(a)$, finis $(n)$.

Numerous three-syllable word forms attested in modern Northern Saami, such as muitalan 'tell.V.Ptc. Pst' and máidnasis 'fairytale.N.Sg. Loc' have been posited as four-syllable words in Proto-Saamic consequently they would have consisted of two feet. Since the word-final syllable in Northern Saami is unstressed (unless, of course, we are dealing with a one-syllable word), the third syllable in these words has also lost its secondary stress, thus muitalan 'tell.V.Ptc.Pst' represents the same structure type as that 
found in (its homonym) muitalan 'tell.V.Prs.Sg1'. An entirely different issue presents itself in the analysis of the Skolt Saami equivalents of these same words mušttlam and mainnsest. Feist applies (at least p. 42) the same interpretation as for Northern Saami (but Feist's understanding of syllable count and the phonological nature of "overshort vowels" is not entirely explicit in the grammar). A different (and in our opinion a more correct) solution is to interpret the forms as having two feet such as is the case for South Saami and protoSaamic. We will provide basis for this understanding in more depth elsewhere. Here let it suffice to say that the so called overshort vowel, i.e. more or less non-existent vowel corresponding to the latus vowel of Northern Saami and Proto-Saamic, can be interpreted as a kind of juncture signaling the edge of a foot. The "overshort vowel" according to our understanding is not an allophone of some vowel phoneme, rather an example of alternation, as in $\varnothing: \hat{a}: a$ observed in the word forms mušttlam (tell.V.Prs.Sg1 or Ptc.Pst) : mušttâl (tell.V.Conneg or tell.V.Imperat.Sg2) : mušttal (tell.V.Prs.Sg3). This interpretation differs from that of Korhonen (1971), but is more or less that of Sammallahti (1998: 142-143). ${ }^{2}$ We will extend the interpretation to such (relatively infrequent) instances as mušttlam tell.V.Prs.Sg1, above, where the last vowel is not posited as the historical vowel centre of a second foot but rather the vowel margin of the first foot. Thus the foot structure of Skolt Saami does not contain a consonant margin or vowel margin, rather its maximal length is: initium, vowel centre, consonant centre, latus, finis (e.g. kiõđâst.).

There is nothing to criticize in the fact that Feist's presentation, mentioned above, parallels in many ways the interpretation of Korhonen (and other earlier researchers). There is, however, reason to draw the readers attention to Feist's example (p. 42) of a "three-syllabled stress group" in the form kiiččéped 'watch.V.Prs.Pl2', where the first $e$ is presented as the latus, and the second $e$ as the vowel margin with the interceding $p$ presented as consonant margin. This interpretation is theoretically impossible due to the suprasegmental palatalization in the sequence $-e^{\prime} p$-, and therefore this sequence must be interpreted as none other than the vowel centre of a second foot followed by the consonant centre (cf. also p. 44). The foot structure here is actually parallel to what is observed in the Skolt Saami word form mušttléped 'recount.V.Ind.Prs.Pl2' with the exception that in the latter word there 
is the consonant $l$ at the beginning of the second foot, whereas in the example kiiččéped there is no initium consonant. If we look for the equivalent of this word form in Northern Saami geahčadehpet, we will notice that an initium consonant is present at the beginning of the second foot. The $-d$ - at the beginning of the second foot has disappeared from many other Skolt Saami word forms, as well. Several of the word forms in this conjugation class (Feist: 4.) have long vowels in the second syllable ( kiiččeep etc.), which would also indicate that the vowel in question cannot be the latus, but rather the vowel centre of a second foot.

Feist has dealt with phonological quantity in two separate places. In 2.5 quantity is approached on the basis of how it is expressed in normal and dictionary orthography. Quantity is addressed again in 3.3, where vowel and consonant quantity are presented more vividly in the light of experimental measurements. In examining quantity from this aspect, the (rather natural) conclusion is reached that the (absolute) durations of the vowel centre and consonant centre are interlinked, i.e. the vowel centre preceding a long consonant cluster or geminate is short; the vowel centre preceding a short consonant cluster or geminate is half long, and the vowel centre preceding a singular consonant is long. The issue of phonological quantity, as seen by the author - does the author posit it as a characteristic of the phoneme or phoneme string, and are there two or three quantities - is left unclarified. Another issue left unaddressed is that both the vowel centre and consonant centre can be short, especially in the non-first foot (e.g. (muštt)léped), but sometimes also in the first foot (e.g. $\log \left(s_{k} k u e^{\prime} t t e d\right)$; p. 119).

When dealing with Skolt Saami regular morphophonology from an entirely synchronic perspective, there are at least four features to be dealt with. Whereas Feist has wielded the concepts of: (a) vowel height, (b) palatalization and (c) gradation in his classification of nominal declension types, he has almost neglected the concept of allegro vs largo, i.e. shortening of the length of the vowel centre and consonant centre (or in Feist's words "reduced forms"), which plays a regular part in verbal and nominal inflection, affecting both grade I and grade II but not grade III morphemes (cf. SKoS pp. 188-189, 199-201). In his presentation of the $8^{\text {th }}$ nominal class (pp. 151-153), Feist provides a paradigm representation of the noun kaappâst 'ladle, scoop' (Table 6o.), which is incomplete but, in fact, compliments a partial 
paradigm provided in SKoS (p. 189). Whereas the paradigm of SKoS indicates only allegro forms in certain cells of the paradigm, Feist only shows a consistent (largo) stem. An augmented partial paradigm will suffice here to illustrate the short comings of both representations: (a) Sg.Nom: kaappâst; (b) Sg.Loc: kapstest kaappstest; (c) Sg.Ill: kapsta kaappsta; (d) Sg.Com Pl.Loc: kapstin kaappstin, and (e) Pl.Nom: kaappâst. A parallel of this phenomenon can be observed in the verb forms mainsted maainsted 'tell.V.Inf' and maainast 'tell.V.Ind.Prs.Sg3' (cf. SKoS pp. 199201; Feist pp. 204, 213). In addition to its stem type presence, allegro vs largo variation is regularly found in the possessive declension of locative singular nominals äkstan ääkkstan 'grandmother.N.Sg.Loc. PxSg1', as well as inflections where the vowel and consonant centres of one foot are immediately followed by a second consonant cluster and subsequent vowel. Thus, synchronically, "stem reduction" occurs in a foot ending in a consonant centre (i.e. having no latus) and followed by a foot with a consonant cluster as the initium. We will return to this issue later.

Although the Grammar of Skolt Saami by Timothy Feist, as is the case with all human accomplishments, is not free of short-comings and errors ${ }^{3}$, it is in many ways a noteworthy step towards a more extensive description of Skolt Saami structure. Besides it is errors and short-comings that move research ahead, because they are what draw our attention to empty pages in research and description of language structure. As we noted above, it is our intention, inspired by this work, to address certain neglected issues exposed here in the near future. We close our scrutiny of this grammar with words of gratitude that we believe others, linguists and members of the Skolt Saami community alike, will join us in: Jõnn spä'sseb šiõgg tuâjast, Teemmaž!

\section{Eino Koponen and Jack Rueter}

\section{Notes}

1. The concept of $/ \varepsilon /$ as a 1oth vowel phoneme is at least present in Sammallahti 1998: 142-143.

2. Actually Sammallahti's interpretation is only implicit in his phonological transcription, where the "overshort vowel" is indicated with ",". The fact that this marker (also) indicates edge of the foot, can be inferred from the suprasegmental palatalization mark in the word form /käлл,se'st/. - Cf. Also Miestamo (2011: 116), who (presumably based on Korhonen) states: "Skolt Saami does not appear to have a clear foot structure."

3. In addition to notes addressed above, let us mention briefly certain issues encountered in the text: Table 1. 
(p. 38) seems to equate the orthographic $j$ and $v$ with approximants. Shouldn't these be $i$ and $u$ respectively? - Long geminates in Skolt Saami linguistic literature are set off by a vertical line between double consonants following a diphthong (p. 39; p. 76 \$2.5). This does not affect clusters or geminates following monophthongs. The grammar, however contains vertical lines on page: 155 "jäämsek'ka" etc.; and they appear to be absent sporadically throughout the text, for example in marking the indicative present ${ }_{3} \mathrm{Pl}$ “kue'đde, vuä'đde” > kue'd'de, vuä'd'Ae (p. 72), as well as indicative past ${ }_{3} \mathrm{Pl}$ "vue'đde" > vue'd'đe (74), “jeäkkal” > jeäk'kal (p. 78), etc. Deverbal nouns in -mõš are indicated as coming with two variants -mõ and-muš (p. 126). While it is true that nouns derived from class-1 verbs share that variation, it is not true that verbs of the classes 2, 3 and 4 do (cf. SKoS p. 159 mainstummuš; pp. 188-189 ââlummuš). - Since the author has used vowel height and palatalization to distinguish subgroups in conjugation (verb types $1 \mathrm{~A}, 1 \mathrm{~B}, 1 \mathrm{C}$, etc.) and declension $\left(1 \mathrm{~A}, 1 \mathrm{~B},{ }_{1} \mathrm{C}\right.$, etc.). Why is it that declension types 5 and 10 are distinguished (pp. 149, 155-156)? Shouldn't they rather be $5 \mathrm{~A}$ (lookkmõš: lookkmõozzžz, lookkmõ šše) and ${ }_{5} \mathrm{C}$ (jäämšěk: jäämšee $\check{k} \check{k}$, jäämšekka)? - Class 6 nominals are shown to have gradation in singular forms (p. 150). Where does this information come from? (cf. SKoS pp. 187-188). - If steehl is given as ?steklo (Russian), would it not be expedient to look for peehl (p. 159) in ?peklo, pjoklo (Russian); cf. Dahl 1882:III:28? -Group B (p. 153-154 vs. 168) provides an incomplete paradigm for the diminutive ǩeâlkaž ̌̌iólkuž (cf. SKoS p. 192). - The noun types for kuâlaž and sä'mmlaž have been erroneously run together (p. 153-154). Group C of the $9^{\text {th }}$ declension type for kuâlaž is not exhibited. - The third person singular imperative form of teâvõõttâd 'dress oneself' is provided without a lowered vowel (p. 211, Table 107). Since this has not been documented in earlier studies, a source should be given. If, indeed, this is a distinctive feature of the paradigm, it cannot be treated as a member of the same conjugation type $1 \mathrm{~A}$. - There are protoSaamic nominative singular forms in Table 20 (p. 10o) that have been copied from the Álgu database, where some of the intervocalic consonants have been marked half-long (nemie, soke ), elsewhere not (ćime, joke). Actually, all instances are assumed to have halflong consonants, but part of the words have been fed into the Álgu database from sources where half-long quantity has not been marked. - Although the grapheme string $<$ llj $>$ indicates a palatal lateral approximate geminate $/ \lambda \lambda /$, the grapheme string $<\mathrm{lj}>$ (at least in the words njääljes and čiólj; p. 62) indicates the phoneme string /lj/. Only part of the adjectives in declension type 4 can be characterized by loss of the final $-s$ in the attribute form (i.e. vuä'mm, but ree'ğğes; p. 174).

\section{Literature}

DAнL = Даль, Владиміръ Ивановичь 1882: Толковый словарь живаго великорускаго языка Владиміра Даля. Второе изданіе, исправленное и значительно умноженное по рукописи автора. Томъ третий. П. С-Петербургъ, Москва. 


\section{Florian Siegl}

$\mathrm{Kk}=$ Moshnikoff, Satu, Moshnikoff, Jouni \& Koponen, Eino 2009: Koltansaamen koulukielioppi. Saamelaiskäräjät. Inari, Finland.

Korhonen, Mikкo 1967: Die Konjugation im Lappischen I. MSFOu 143. Suomalais-Ugrilainen Seura. Helsinki.

- 1971: Ehdotus koltanlapin Suonikylän (nyk. Sevettijärven) murteen fonemaattiseksi transkriptioksi. - Erkki Itkonen, Terho Itkonen, Mikko Korhonen \& Pekka Sammallahti (eds): Lapin murteiden fonologiaa. Castrenianumin toimitteita 1. SuomalaisUgrilainen Seura. Helsinki. 69-86.

- 1973: Kieliopin pääkohdat. - Korhonen, Mikko, Mosnikoff, Jouni \& Sammallahti, Pekka: Koltansaamen opas. Castrenianumin toimitteita 4. Suomalais-Ugrilainen Seura. Helsinki. 9-98.

- 1974: Die Konjugation im Lappischen II. MSFOu 155. Suomalais-Ugrilainen Seura. Helsinki.

Miestamo, Matti 2011: Skolt Saami: a typological profile. - JSFOu 93. 111-145.
Miestamo, Matti \& Koponen, Eino 2015: Negation in Skolt Saami. - Matti Miestamo, Anne Tamm \& Beáta Wagner-Nagy (eds): Negation in Uralic languages. Typological Studies in Language. Benjamins. Amsterdam. 353-375.

Mosnikoff, SAtu 1992: Maaddârää'jji mainnâz. Girjegiisá. Utsjoki, Finland.

Nickel, Klaus Peter \& Sammallahti, PeKKA 2011: Nordsamisk grammatikk. Davvi girji. Karasjok, Norway.

Sammallahti, Pekka 1998: The Saami languages: An introduction. Davvi girji. Karasjok, Norway.

- 2012: Taas mentiin. Koltansaamen lukemisto. Toimittanut Marko Jouste. Publications of the Giellagas Institute 14. Oulun yliopisto. Oulu.

SKoS = Sammallahti, Pekka \& Mosnikoff, Jouni 1991: Suomi-koltansaame sanakirja. Girjegiisá. Utsjoki, Finland.

Ylikoski, JUSSI 2009: Non-finites in North Saami. MSFOu 257. SuomalaisUgrilainen Seura. Helsinki. 